\title{
A revised classification of the cleft lip and palate
}

\author{
Mansoor Khan MBBS, Hidayat Ullah FCPS(Plast), Shazia Naz MBBS, Tariq Iqbal MBBS, \\ Tahmeed Ullah FCPS(Plast), Muhammad Tahir FRCS, Obaid Ullah FRCS
}

\begin{abstract}
M Khan, H Ullah, S Naz, et al. A revised classification of the cleft lip and palate. Can J Plast Surg 2013;21(1):48-50.
\end{abstract}

BACKGROUND: Submucous cleft palate is character-

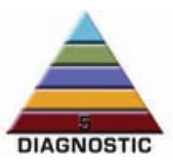

ized by muscular diastasis of the velum in the presence of intact mucosa with variable combinations of bifid uvula and hard palatal defect. Submucous cleft palate is indicated as a separate entity in most previous classifications but it has never been properly classified on an anatomical basis.

OBJECTIVES: To revise the Smith-modified Kernahan 'Y' classification of cleft lip and palate deformities, and to describe the different anatomical subtypes of submucous cleft palate.

METHODS: The present study was conducted in Hayatabad Medical Complex, Abasin Hospital and Aman Hospital Peshawar, Pakistan, from November 2010 to December 2011. All patients who presented to the outpatient departments with cleft lip and palate, with the exception of previously operated cases, were included. All cases were described according to the Smith-modified Kernahan ' $Y$ ' classification and the authors' revised Smith-modified Kernahan 'Y' classification. All of the data were organized and analyzed using SPSS version 17 (IBM Corporation, USA). RESULTS: A total of 163 cases of cleft lip and palate deformities were studied, of which $59.5 \%$ were male and $40.5 \%$ were female. Smith modification of the Kernahan ' $Y$ ' classification completely described the cleft deformities in $93.9 \%$ of patients. However, while the Kernahan 'Y' classification represented the submucous cleft palate, it did not describe its different anatomical subtypes in $6.13 \%$ of patients. The revised Smith-modified Kernahan ' $Y$ ' classification completely described the cleft deformities of the entire study population, including the different submucous cleft palate patients.

DISCUSSION: The Smith alphanumeric modification of the Kernahan ' $Y$ ' classification of cleft lip and palate came into existence after a long search and a series of modifications over the past century. This classification system describes the cleft region, site of the cleft, degree of the cleft, rare and asymmetrical clefts, and are computer database friendly. However, this classification did not describe the different anatomical subtypes of submucous cleft palate that have variable relationships with velopharyngeal insufficiency. CONCLUSION: The revised Smith-modified Kernahan 'Y' classification described in the present study can describe all types of cleft lip and palate deformities in addition to the different types of submucous cleft palate deformities.

Key Words: Cleft lip; Cleft palate; Submucous cleft palate; Velopharyngeal insufficiency

$\mathrm{C}$ left lip and palate represent the most common oromaxillofacial congenital anomalies and affect one in 500 to one in 1000 newborns worldwide (1). The surgeon must account for the diverse characteristics associated with the severity of cleft lip and palate deformities (2). To precisely describe the types, exact location and extent of the deformities, surgeons and nonmedical clerks need a classification system that is easy to understand and document, and that transcends language barriers and is applicable to computer data analysis (1).

The first most commonly accepted classification was presented by Kernahan and Stark (1) in 1958, who described all common types of cleft lip/palate, complete unilateral cleft lip/palate and the isolated posterior cleft palate in a symbolic classification system. To describe the unusual types of cleft deformities, Kernahan modified his

\section{Une classification révisée de la fente labiale et palatine}

HISTORIQUE : La fente palatine sous-muqueuse se caractérise par un diastasis musculaire du voile du palais en présence d'une muqueuse intacte comportant diverses combinaisons de luette bifide et d'anomalie du palais dur. La fente palatine sous-muqueuse était considérée comme une entité distincte dans la plupart des classifications antérieures, mais on ne lui a jamais attribué de classification convenable sur le plan anatomique.

OBJECTIFS : Examiner la classification en «Y » de Kernahan modifiée par Smith des fentes labiales et palatines et décrire les divers sous-types anatomiques de la fente palatine sous-muqueuse.

MÉTHODOLOGIE : La présente étude a été menée au complexe médical Hayatabad de Peshawar, à l'hôpital Abasin de Peshawar et à l'hôpital Aman de Peshawar, au Pakistan, de novembre 2010 à décembre 2011. Tous les patients qui se sont présentés aux consultations externes et qui avaient une fente labiale et palatine ont participé à l'étude, à l'exception des cas déjà opérés. Les auteurs ont décrit tous les cas conformément à la classification en « Y » de Kernahan modifiée par Smith et à leur révision de cette classification. Ils ont organisé et analysé toutes les données à l'aide du logiciel SPSS, version 17 (IBM Corporation, États-Unis).

RÉSULTATS : Au total, les chercheurs ont étudié 163 cas de fentes labiales et palatines, répartis entre 59,5\% d'hommes et 40,5\% de femmes. La classification en « Y » de Kernahan modifiée par Smith décrivait tous les éléments des anomalies palatines chez 93,9\% des patients. Cependant, même si la classification en " Y » de Kernahan incluait la fente palatine sousmuqueuse, elle n'en décrivait pas les divers sous-types anatomiques chez $6,13 \%$ des patients. La classification en « Y » de Kernahan modifiée par Smith et révisée décrivait tous les éléments des anomalies palatines de toute la population à l'étude, y compris chez les patients ayant diverses fentes palatines sous-muqueuses.

EXPOSÉ : La modification alphanumérique par Smith de la classification en «Y » de la fente labiale et palatine de Kernahan a été créée après de longues recherches et une série de modifications apportées sur une periode d'un siècle. Ce système de classification décrit la région, le foyer et le degré de la fente ainsi que les fentes rares et asymétriques, et il est adapté aux bases de données informatiques. Cependant, il ne décrivait pas les divers sous-types de fente palatine sous-muqueuse qui ont des relations variables avec l'insuffisance vélopharyngée.

CONCLUSION : La classification en «Y » de Kerhanahn modifiée par Smith décrite dans la présente étude peut décrire tous les types de fentes labiales et palatines, en plus des divers types de fentes palatines sousmuqueuses. 


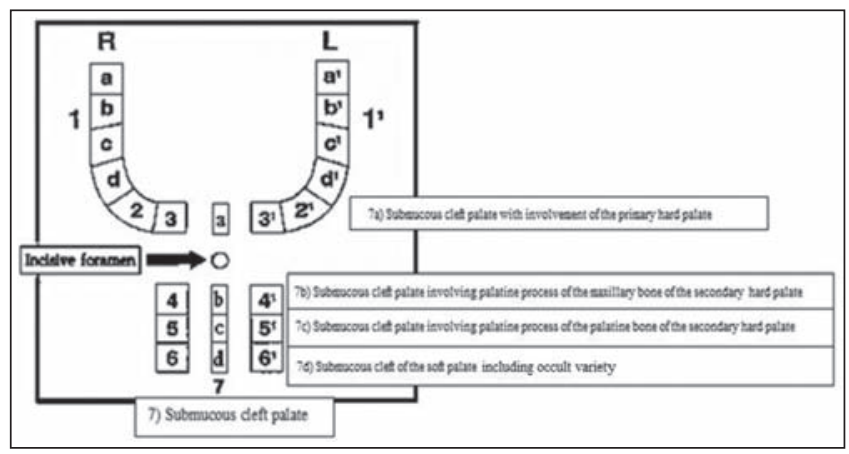

Figure 1) A revised classification of the cleft lip and palate

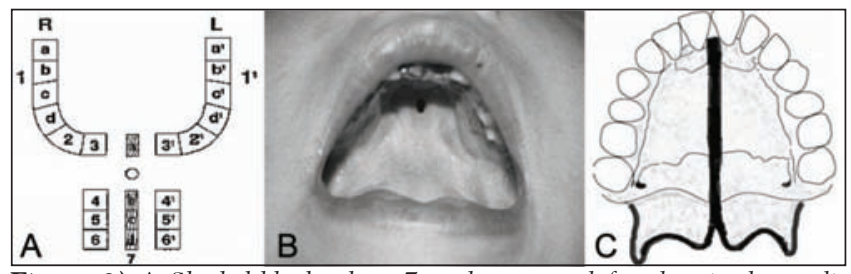

Figure 2) A Shaded blocks show 7a-submucous cleft palate in the modified Smith classification. B 7a-submucous cleft palate with congenital anterior palatal fistula. C Bold line indicates the extent of involvement in the 7a-submucous cleft palate

submucous cleft palate was denoted by 'a' but it did not describe the different varieties of the submucous cleft palate because it can involve the hard palate to different levels as observed in our study population. Submucous cleft palate is a type of cleft deformity in which muscles are malaligned and malinserted with intact oral mucosa. The hallmark signs usually associated with submucous cleft palate are bifid uvula, V-shaped notching of the hard palate and a translucent line in the midline of the soft palate (zona pellucida) $(4,5)$. Only $10 \%$ of patients with submucous cleft palate are symptomatic (4). Velopharyngeal insufficiency is an abnormality of the sphincter formed by the soft palate and the pharynx leading to abnormal speech. The primary issue in the management of the submucous cleft palate is the delayed presentation of the patients. Patients often present after speech has already developed, with abnormal speech as the major complaint. Unfortunately, due to the delayed presentation, surgical repair of the submucous cleft palate does not correct speech (6). Early diagnosis and identification of the types of submucous cleft palate that will lead to a speech abnormality before speech development is the key to successful management of these patients. In the revised Smith-modified Kernahan 'Y' classification of the cleft lip and palate presented in the current study, we have incorporated different varieties of the submucous cleft, which can provide an anatomical basis for the severity of velopharyngeal insufficiency.

\section{METHODS}

The present multicentre descriptive cross-sectional study was conducted at the Hayatabad Medical Complex, Abasin Hospital and Aman Hospital, Peshawar, Pakistan, and included all cleft lip and palate patients presenting to the outpatient departments from November 2010 to December 2011, irrespective of age and sex. All patients who were previously operated were excluded due to the possibility of bias in the determination of the cleft deformity type. Following informed consent, all patient data were recorded using a questionnaire, history and thorough physical examination to determine the type of cleft deformity. The tools for the diagnoses of submucous cleft palate were speech assessment (hypernasality occurring for sounds other than 'm', 'n', 'ng' and nasal air escape for pressure consonants), intraoral examination under illumination, and digital palpation of the hard palate and seagull sign on nasopharyngoscopy. The cleft deformities of all patients were classified on the basis of Smith modification of the Kernahan 'Y' classification and our revised Smith modified Kernahan 'Y' classification (Figure 1). The percentages of deformities completely described by the Smith-modified

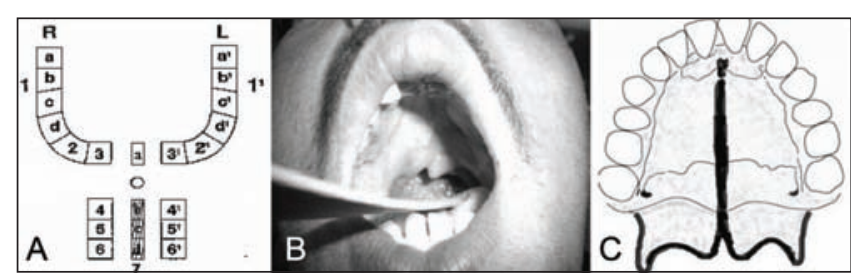

Figure 3) A Shaded blocks shows 7b-submucous cleft palate in the modified Smith classification. B 7b-submucous cleft palate. C Bold line indicates the extent of involvement in the $7 b$-submucous cleft palate

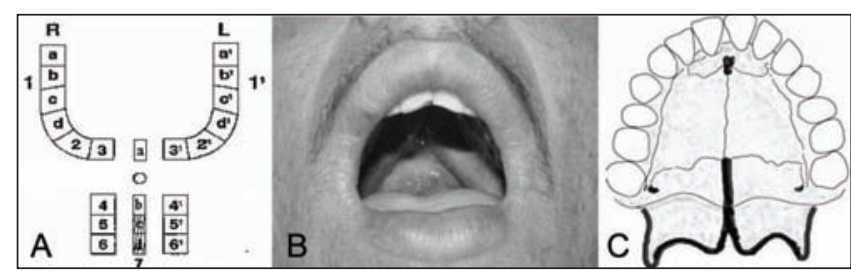

Figure 4) A Shaded blocks show 7c-submucous cleft palate in the modified Smith classification. B 7c-submucous cleft palate. C Bold line indicates the extent of involvement in the 7c-submucous cleft palate

Kernahan ' $Y$ ' classification and the revised Smith-modified Kernahn 'Y' classification was determined using SPSS version 17 (IBM Corporation, USA).

Description of the revised Smith-modified Kernahan ' $Y$ ' classification The submucous cleft palate was denoted by number ' 7 ', which is subdivided into four segments (Figure 1);

A.Submucous cleft palate with involvement of the primary hard palate lying anterior to the incisive foramen and posterior to the alveolus (Figure 2).

B.Submucous cleft palate with involvement of the palatine process of the maxillary bone of the secondary hard palate (Figure 3).

C. Submucous cleft palate with involvement of the palatine process of the palatine bone of the secondary hard palate (Figure 4).

D. Submucous cleft of the soft palate including occult submucous cleft palate (Figure 5).

\section{RESULTS}

A total of 163 patients were included in the present study, with ages ranging from 10 days to 64 years with an SD of 6.76 years, of whom $59.5 \%(n=97)$ were male and $40.5 \%(n=66)$ were female. Smith modification of the Kernahan ' $Y$ ' classification completely described $93.9 \%$ $(n=153)$ of the patients with a cleft deformity. The Smith modification of the Kernahan 'Y' classification (Table 1) represented submucous cleft palate with letter 'a' but did not explain its different varieties in $6.13 \%(n=10)$ of patients. On the other hand, the revised Smithmodified Kernahan 'Y' classification (Figure 1, Table 2) described the cleft deformities of all patients including the different types of the submucous cleft palate in detail.

Of 10 patients with submucous cleft palate, five (50\%) were 7c (submucous cleft palate with involvement of the palatine process of the palatine bones), two (20\%) were $7 \mathrm{~d}$ (submucous cleft palate without hard palate involvement) and $7 \mathrm{~b}$ (submucous cleft palate with involvement of the whole of the secondary hard palate).

\section{DISCUSSION}

The management of patients with cleft deformities is a multidisciplinary task. Medical and nonmedical personnel involved in record keeping need a precise, comprehensive and complete classification system. The search for the ideal classification system was started in 1922 by Davis et al (7) and, finally, due to the efforts of Kernahan et al $(8,9)$, Millard et al (10) and Smith et al (3), an alphanumeric classification system emerged, which is largely accepted and used worldwide today $(11,12)$. This classification system describes the cleft region, site of the cleft, degree of the cleft, and rare and asymmetrical clefts. This classification 


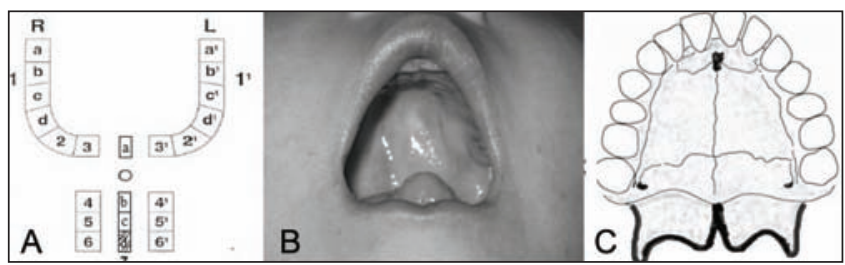

Figure 5) A Shaded blocks show 7d-submucous cleft palate in the modified Smith classification. B 7d-submucous cleft palate. C Bold line indicates that only the soft palate is involved in the 7d-submucous cleft palate

TABLE 1

Distribution of the study population according to the Smith classification

\begin{tabular}{|c|c|c|c|c|c|}
\hline S/no & $\begin{array}{c}\text { Type of cleft } \\
\text { deformity }\end{array}$ & $\begin{array}{l}\text { Patients, } \\
\text { n (\%) }\end{array}$ & S/no & $\begin{array}{c}\text { Type of cleft } \\
\text { deformity }\end{array}$ & $\begin{array}{l}\text { Patients, } \\
\text { n (\%) }\end{array}$ \\
\hline 1 & 00/1'2' & $1(0.6)$ & 18 & $1 c, 45 / 4^{\prime} 5^{\prime}$ & $1(0.6)$ \\
\hline 2 & $00 / 1 ' 2$ ' & $1(0.6)$ & 19 & 1c,6/6' & $1(0.6)$ \\
\hline 3 & 00/1'6' & $37(22.7)$ & 20 & $1 \mathrm{c} / 00$ & $3(1.8)$ \\
\hline 4 & $00 / 1 b^{\prime}$ & $2(1.2)$ & 21 & $1 c / 1^{\prime} 6^{\prime}$ & $1(0.6)$ \\
\hline 5 & $00 / 1 c^{\prime}$ & $3(1.8)$ & 22 & $1 c / 1 c^{\prime}$ & $1(0.6)$ \\
\hline 6 & $00 / 1 c^{\prime} 6$ ' & $1(0.6)$ & 23 & $1 c 2 / 00$ & $1(0.6)$ \\
\hline 7 & 00/1d'2' & $3(1.8)$ & 24 & $1 c 2 / 1 c^{\prime} 2^{\prime}$ & $1(0.6)$ \\
\hline 8 & 1,56/1',5'6' & $1(0.6)$ & 25 & $1 c 56 / 1 c^{\prime} 5{ }^{\prime} 6^{\prime}$ & $1(0.6)$ \\
\hline 9 & $1 / 00$ & $1(0.6)$ & 26 & $1 \mathrm{~d} 2 / 00$ & $1(0.6)$ \\
\hline 10 & $1 / 1^{\prime}$ & $1(0.6)$ & 27 & $45 / 1 c^{\prime}, 4{ }^{\prime}{ }^{\prime}$ & $1(0.6)$ \\
\hline 11 & $12 / 00$ & 2 (1.2) & 28 & $56 / 1^{\prime}, 5^{\prime} 6$ ' & $1(0.6)$ \\
\hline 12 & $12 / 1 ' 2^{\prime}$ & $1(0.6)$ & 29 & $56 / 5^{\prime} 6^{\prime}$ & 31 (19.0) \\
\hline 13 & 12/1'2' & $1(0.6)$ & 30 & $6 / 6$ & $11(6.7)$ \\
\hline 14 & $16 / 00$ & $14(8.6)$ & 31 & $6 / 6^{\prime}$ & $2(1.2)$ \\
\hline 15 & 16/1'6' & 25 (15.3) & 32 & $a / a^{\prime}$ & $10(6.1)$ \\
\hline 16 & $1 \mathrm{~b} / 00$ & $1(0.6)$ & Total & & $163(100)$ \\
\hline 17 & 1b2/1b'2' & $1(0.6)$ & & & \\
\hline
\end{tabular}

Bolded values indicate submucous cleft palate. S/no Serial number

system is also computer database friendly (3). The submucous cleft palate is a variety that is indicated in the Smith-modified Kernahan ' $\mathrm{Y}$ ' classification by the letter 'a', but its details are not decribed in this classification system. Some of the submucous cleft palate is associated with velopharyngeal insufficiency depending on its severity. In this modification of the Smith classification, we have classified submucous cleft palate and incorporated it in the Smith classification.

A total of 163 patients with different cleft deformities were included in the present study, including 10 patients with submucous cleft palate patients. The Smith-modified Kernahan 'Y' classification completely described $93.9 \%$ of the patients with cleft deformity, while it could not classify $6.13 \%$ cases with different types of submucous cleft palate. On the other hand, the revised Smith-modified Kernahan ' $Y$ ' classification completely described all cases of cleft lip and palate in detail, including different types of the submucous cleft palate.

The submucous cleft palate and its association with velopharyngeal insufficiency has been described by several authors (13-16). However, its different anatomical types have never been properly described. The objectives of the present modification were to classify submucous cleft palate on the basis of extent of involvement of the hard palate, incorporate it in the existing most acceptable alphanumeric classification system of the cleft deformities and initiate research on the associated velopharyngeal insufficiency with different types of the submucous cleft palate.

\section{CONCLUSION}

The different subclasses of submucous cleft palate can be easily described by the revised Smith-modified Kernahan 'Y' classification of the cleft lip and palate. Further studies to establish the degree of associated velopharyngeal insufficiency in different types of the submucous cleft palate are recommended.
TABLE 2

Distribution of the study population according to the revised classification of cleft lip and palate

\begin{tabular}{|c|c|c|c|c|c|}
\hline S/no & $\begin{array}{l}\text { Type of cleft } \\
\text { deformity }\end{array}$ & $\begin{array}{l}\text { Patients, } \\
\text { n (\%) }\end{array}$ & S/no & $\begin{array}{l}\text { Type of cleft } \\
\text { deformity }\end{array}$ & $\begin{array}{l}\text { Patients, } \\
\text { n (\%) }\end{array}$ \\
\hline 1 & 00/1'2' & $1(0.6)$ & 19 & $1 c, 6 / 6$ & $1(0.6)$ \\
\hline 2 & 00/1'2' & $1(0.6)$ & 20 & $1 \mathrm{c} / 00$ & $3(1.8)$ \\
\hline 3 & $00 / 1^{\prime} 6^{\prime}$ & 37 (22.7) & 21 & $1 c / 1^{\prime} 6^{\prime}$ & $1(1.8)$ \\
\hline 4 & $00 / 1 b '$ & $2(1.2)$ & 22 & $1 c / 1 c^{\prime}$ & $1(0.6)$ \\
\hline 5 & 00/1c' & $3(1.8)$ & 23 & $1 \mathrm{c} 2 / 00$ & $1(0.6)$ \\
\hline 6 & $00 / 1 c^{\prime} 6^{\prime}$ & $1(0.6)$ & 24 & 1c2/1c'2' & $1(0.6)$ \\
\hline 7 & 00/1d'2' & $3(1.8)$ & 25 & 1c56/1c'5'6' & $1(0.6)$ \\
\hline 8 & $1,56 / 1^{\prime}, 5^{\prime} 6^{\prime}$ & $1(0.6)$ & 26 & $1 \mathrm{~d} 2 / 00$ & $1(0.6)$ \\
\hline 9 & $1 / 00$ & $1(0.6)$ & 27 & $45 / 1 c^{\prime}, 4{ }^{\prime}{ }^{\prime}$ & $1(0.6)$ \\
\hline 10 & $1 / 1^{\prime}$ & $1(0.6)$ & 28 & $56 / 1^{\prime}, 5^{\prime} 6^{\prime}$ & $1(0.6)$ \\
\hline 11 & $12 / 00$ & $2(1.2)$ & 29 & $56 / 5^{\prime} 6^{\prime}$ & 31 (19.0) \\
\hline 12 & 12/1'2' & $1(0.6)$ & 30 & $6 / 6^{\prime}$ & $11(6.7)$ \\
\hline 13 & 12/1'2' & $1(0.6)$ & 31 & $6 / 6$ & $2(1.2)$ \\
\hline 14 & $16 / 00$ & $14(8.6)$ & 32 & $7 a$ & $1(0.6)$ \\
\hline 15 & 16/1'6' & 25 (15.3) & 33 & $7 b$ & $2(1.2)$ \\
\hline 16 & $1 b / 00$ & $1(0.6)$ & 34 & $7 c$ & $5(3.1)$ \\
\hline 17 & 1b2/1b'2' & $1(0.6)$ & 35 & $7 d$ & $2(1.2)$ \\
\hline 18 & 1c,45/4'5' & $1(0.6)$ & Total & & $163(100.0)$ \\
\hline
\end{tabular}

Bolded values indicate submucous cleft palate subtypes according to the revised classification for cleft lip and palate. S/no Serial number

DISCLOSURES: The authors report no financial or other conflict of interest relevant to the subject of this article. No financial support was obtained from any organization.

\section{REFERENCES}

1. Liu Q, Yang ML, Li ZJ, et al. Simple and precise classification for cleft lip and palate: A five-digit numericalrecording system. Cleft Palate Craniofac J 2007;44:465-8.

2. Ortiz-Posadas MR, Vega-Alvarado L, Maya-Behar J. A new approach to classify cleft lip and palate. Cleft Palate Craniofac J 2001;38:545-50.

3. Smith AW, Khoo AK, Jackson IT. A modification of the Kernahan "Y" classification in cleft lip and palate deformities. Plast Reconstr Surg 1998;102:1842-7.

4. Wales CJ, Corsar K, Devlin MF. Submucous cleft palate. Br Dent J 2009;207:254.

5. Skoll PJ. Submucous cleft palate: An aid to diagnosis. Plast Reconstr Surg 2004;113:1865-6.

6. Ysunza A, Pamplona MC, Mendoza M et al. Surgical treatment of submucous cleft palate: A comparative trial of two modalities for palatal closure. Plast Reconstr Surg 2001;107:9-14.

7. Davis JS, Ritchie HP. Classification of congenital cleft of the lip and palate. JAMA 1922;79:1323-7.

8. Kernahan DA, Stark RB. A new classification for cleft lip and cleft palate. Plast Reconstr Surg Transplant Bull 1958;22:435-41.

9. Kernahan DA. The striped Y - a symbolic classification for cleft lip and palate. Plast Reconstr Surg 1971;47:469-70.

10. Millard R, Balber G, Philips BW. A data collection system for cleft lip and palate: I. Surgical evaluation. Cleft Palate J 1967;4:277-90.

11. Elahi MM, Jackson IT, Elahi O, et al. Epidemiology of cleft lip and cleft palate in Pakistan. Plast Reconstr Surg 2004;113:1548-55.

12. Luijsterburg AJ, Vermeij-Keers C. Ten years recording common oral clefts with a new descriptive system. Cleft Palate Craniofac J 2011;48:173-82.

13. Kaplan EN. The occult submucous cleft palate. Cleft Palate J 1975;12:356-68.

14. Kuehn DP, Ettema SL, Goldwasser MS, Barkmeier JC, Wachtel JM. Magnetic resonance imaging in the evaluation of occult submucous cleft palate. Cleft Palate Craniofac J 2001;38:421-31.

15. Elsahy NI. The modified striped Y-a systematic classification for cleft lip and palate. Cleft Palate J 1973;10:247-50.

16. Jensen BL, Kreiborg S, Dahl E, Fogh-Andersen P. Cleft lip and palate in Denmark, 1976-1981: Epidemiology, variability, and earlysomatic development. Cleft Palate J 1988;25:258-69. 